\title{
Business Process Simulation Game as a Business Process Learning Tool for Retail Companies
}

\author{
Joella $^{1, a}$, Yulia ${ }^{2, b}$, Andreas Handojo ${ }^{3, c}$ \\ 1,2,3Petra Christian University, Jl. Siwalankerto 121-131, Surabaya 60236, Indonesia \\ ajoellakurniawan@gmail.com, byulia@petra.ac.id, chandojo@petra.ac.id
}

\begin{abstract}
Game-based Learning has become one of the most developed learning methods in this 21st century. Game-based Learning is a good learning method because it can create a virtual world where players can simulate real-world problem-solving. A business process is a series of interrelated activities to achieve certain business goals, executed sequentially or parallel, both inside and outside the company. The complexity of business processes causes the learning process to be less than optimal, if only in the form of theoretical exposure. Practices are needed to hone students' business process management skills, which will be too risky to be done in the real world. Therefore, this research develops a business process simulation game to facilitate students in practicing their business process management skills. The author analyzed the existing business process simulation games, determined the game system design, developed the game, tested the game, and distributed questionnaires to users. Based on the results of testing and implementing the system that has been done, the game developed in this research has a positive impact on users. The features in the game are running well and as expected. The game provides benefits to both teachers and students, so this game is suitable for being used as retail companies' business process learning tool.
\end{abstract}

Keywords: Game-based learning, simulation-based learning, enterprise resource planning, business process.

\section{Introduction}

Technological advances cannot be avoided in this life, because every innovation created always provides positive benefits for human life. [7] One of the impacts of technological advances is the creation of games. A game is an interactive activity that focuses on achievement, some actors play it, and there are opponents. At first, the appearance of games was only for the entertainment sector, but over time, games have been widely developed so that they can now be used as simulation tools in the fields of education, business, medicine, politics, military, and others. [14]

In education, there are many learning methods that teachers can use. Learning methods can help encourage students to achieve high achievement (results). A learning method that provides great benefits to a lesson does not necessarily benefit other lessons. Therefore, teachers need to consider which learning method is the most appropriate. If the teacher succeeds in applying the right learning method, achieving learning objectives is more effective. [6] According to [5], one of the qualifications to become a teacher in the 21 st century is technological literacy, and should even be able to translate technological advances appropriately and proportionally to the learning process. This happens because today's students have been used to technology since childhood. This is one of the reasons why Game-based Learning is one of the most developed learning methods in the 21st century. In addition, Gamebased Learning is good as a learning method because it can create a virtual world where players can simulate solving realworld problems. Much work has been done to prove that this learning method is succeeded to increase students' motivations in the learning process [10],

Game-based learning can be applied to all ages, both for children under five to adults. For children, [1] developed simple games that can build children's awareness of obesity. [12] developed an educational game that could help middle school students understand colloids. For college students, [3] developed a Supply Chain Management simulation game to understand the theory and put it into practice. [8] has even developed a Catholic religious education game that is not aimed at certain age groups.

A business process is a series of interrelated activities to achieve certain business goals which are executed sequentially or parallel, both inside and outside the company. The complexity of business processes causes the learning process to be less than optimal if only in the form of theoretical exposure. Practices are needed to hone students' business process management skills, but if they practice in the real world, of course it will be very high risk. Therefore, a business process simulation game is needed to facilitate the students in practicing their business process management skills based on what they have learned in class. Monsoon SIM, Sim Companies, and Virtonomics are examples of web-based business process simulation games used as a business process learning tool. Virtonomics is not suitable as a business process learning tool in class because it is not flexible, while MonsoonSIM and SimCompanies are suitable as business process learning tools in class because they are more flexible and provide special features for facilitators (teachers). Currently, MonsoonSIM and SimCompanies are widely used by universities or other educational institutions. However, both are paid, so this research developed a business process simulation game as a learning tool for Petra Christian University students. This business process simulation game offers an interactive environment and is trial-and-error risk-free so that students can learn while practicing decision making in business based on theories that have been learned in the classroom. Students can learn how to maintain finances and minimize business risks that may occur. With this simulation game, it is hoped that students can more easily understand business processes and have experience in how to do company management. 


\section{Theoretical Foundation}

\subsection{Business Process}

Business is an organizational unit that manages resources to provide products and services needed by customers. A process is a series of actions in carrying out operational activities to produce certain outputs. So, a business process is a series of activities that take one or many inputs and create an output that is useful to customers. [17] A business process must have clear objectives, have input, have outputs, use resources, have a number of activities that exist in several stages, influence the organization, and create value that is beneficial to customers. [13]

\subsection{Game-based Learning}

Game-based learning is a learning method that uses game applications specifically designed to support the learning process. The game is designed in accordance with the learning material and aims to make it easier for players to understand the applications of the learning material in the real world. Game-based learning can create a learning environment that is motivating, fun, and increases creativity. Learning with a playful approach is able to stimulate students' emotional, intellectual, and psych motoric. [9]

[16] concluded the opinions of other researchers regarding the development of game-based learning. Game-based learning is considered to have many positive influences in the learning process. This technology allows the learning process to be individualized. It means that the learning process follows the characteristics and understanding of the players themselves. Game-based learning can also foster various points of view and provide various ways of approaching understanding problems. Players can also learn to cooperate with other players in a team or work together between groups. Finally, game-based learning trains players to focus on achieving targets in a limited time, which is very important to prepare themselves to enter the world of work.

\section{System Analysis and Design}

\subsection{Research Problems}

1. How suitable is a business process simulation game to be a business process learning tool?

2. How useful is the business process simulation game as a learning tool for teachers and students?

\subsection{Research Purposes}

This research aims to develop a business process simulation game for retail companies as a business process learning tool.

\subsection{Research Methodology}

\section{- System analysis}

The author analyzed the existing simulation games, namely MonsoonSIM, SimCompanies, and Virtonomics. This analysis is carried out to determine the advantages and disadvantages of each game and to know what features should be in a simulation game. After studying the three games, the author determined what features will be developed in this study. Further explanation is in section 3.4 .
- System design

After conducting a system analysis, the author designed the system that would be developed. The author defined functional requirements in this process, described how a system is formed, and prepared for implementation. Further explanation is in section 3.6.

- System development

After analyzing and finishing the system design, the author developed the system. The development of this game system used Node.js, Express.js, MongoDB, and Mongoose.

- System testing and questionnaire

The game developed in this study was tested directly by the user and then the author distributed a questionnaire containing a list of questions related to research problems, regarding user satisfaction and the benefits that users received from the game developed. Further explanation is in section 4.

\subsection{System Analysis}

During the writing of the thesis, analysis was carried out on several similar simulation games, namely MonsoonSIM [18], SimCompanies [4], and Virtonomics [15]. The analysis is carried out to find out the features that already exist in the three simulation games and to find out which features need to be added. The three main points of comparison when analyzing the three games are the game model, modules, and game time calculations. The summary of the results of the comparison of differences can be seen in Table 1.

\subsection{Feature Mapping}

After analyzing the system and determining the modules to be made, a feature mapping of each module is carried out. The results of the feature mapping are described in Table 2.

\subsection{Interface Design}

\subsubsection{For Players}

Interface design for players consists of 5 pages: home page, finance page, forecast page, loans page, and procurement page. Home page (Figure 1) is the main page of player game. In this page, player can see their company's financial situation, see their retails and warehouses, and players can click menu "Join Game" to join any facilitator game. Besides that, this page also has buttons that can take players to other pages.

The finance page (Figure 2) is a page where players can see the details of their company financial report. Financial reports available on this page are the profit $\&$ loss report, balance sheet, and trial balance.

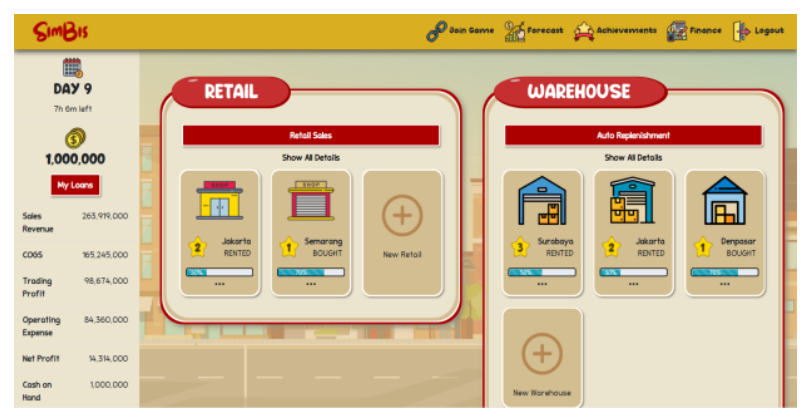

Figure 1. Interface design for players - home page. 
Table 1. System analysis comparison table.

\begin{tabular}{|c|c|c|c|c|}
\hline Compa-rison & MonsoonSIM & Sim Companies & Virtonomics & SimBis \\
\hline Game model & $\begin{array}{l}\text { The game model is in the form of } \\
\text { competition, with the facilitator as } \\
\text { the organizer }\end{array}$ & $\begin{array}{l}\text { The game is played by } \\
\text { individual players and has no } \\
\text { end. Players are given the } \\
\text { opportunity to continuously } \\
\text { develop their company }\end{array}$ & $\begin{array}{l}\text { The game is played by } \\
\text { individual players and has no } \\
\text { end. Players are given the } \\
\text { opportunity to continuously } \\
\text { develop their company }\end{array}$ & $\begin{array}{l}\text { It consists of two types of games: } \\
\text { facilitator games as competition } \\
\text { game and player games as } \\
\text { individual game }\end{array}$ \\
\hline Modules & $\begin{array}{l}\text { finance, procurement, retail \& } \\
\text { sales, marketing, warehouse, } \\
\text { forecast, business to business, } \\
\text { production, material requirement } \\
\text { planning, maintenance, human } \\
\text { resource, and customer service. }\end{array}$ & $\begin{array}{l}\text { finance, procurement, retail \& } \\
\text { sales, warehouse, business to } \\
\text { business, production, material } \\
\text { requirement planning, and } \\
\text { human resource. }\end{array}$ & $\begin{array}{l}\text { finance, procurement, retail \& } \\
\text { sales, marketing, warehouse, } \\
\text { business to business, } \\
\text { production, material } \\
\text { requirement planning, human } \\
\text { resource, and service sector. }\end{array}$ & $\begin{array}{l}\text { finance, procurement, retail \& } \\
\text { sales, warehouse, and forecast }\end{array}$ \\
\hline Finance module & $\begin{array}{l}\text { profit \& loss, balance sheet, trial } \\
\text { balances, loans, dan delinquents }\end{array}$ & $\begin{array}{l}\text { income and expense summary, } \\
\text { cashflow report, balance sheet, } \\
\text { and income statement }\end{array}$ & $\begin{array}{l}\text { income, expense, and profit } \\
\text { report }\end{array}$ & $\begin{array}{l}\text { profit \& loss, balance sheet, trial } \\
\text { balances, and loans }\end{array}$ \\
\hline $\begin{array}{l}\text { Procurement } \\
\text { module }\end{array}$ & $\begin{array}{l}\text { Purchases can be made to vendors } \\
\text { from the game system }\end{array}$ & $\begin{array}{l}\text { Purchases can be made to other } \\
\text { players or to vendors from the } \\
\text { game system }\end{array}$ & $\begin{array}{l}\text { Purchases can be made to other } \\
\text { players }\end{array}$ & $\begin{array}{l}\text { Purchases can be made to vendors } \\
\text { from the game system }\end{array}$ \\
\hline $\begin{array}{l}\text { Retail \& sales } \\
\text { module }\end{array}$ & $\begin{array}{l}\text { Retail is made with the concept of } \\
\text { renting, so the fee is based on } \\
\text { rental costs. A retail upgrade } \\
\text { means expanding the building. }\end{array}$ & $\begin{array}{l}\text { Retail is made with a building } \\
\text { concept, so the costs are based } \\
\text { on the cost of building } \\
\text { materials. A retail upgrade } \\
\text { means increasing sales. }\end{array}$ & $\begin{array}{l}\text { Retail is made with the concept } \\
\text { of renting, so the fee is based on } \\
\text { rental costs. Retail cannot be } \\
\text { upgraded. }\end{array}$ & $\begin{array}{l}\text { Players can choose to buy/rent } \\
\text { retail. A retail upgrade means } \\
\text { expanding the building. To } \\
\text { increase sales, retail should not } \\
\text { stockout. }\end{array}$ \\
\hline $\begin{array}{l}\text { Ware-house } \\
\text { module }\end{array}$ & $\begin{array}{l}\text { Warehouse is made with the } \\
\text { concept of renting, so the fee is } \\
\text { based on rental costs. A warehouse } \\
\text { upgrade means expanding the } \\
\text { building. Cannot make sales } \\
\text { through warehouse. }\end{array}$ & $\begin{array}{l}\text { The warehouse is owned by the } \\
\text { player since the beginning of the } \\
\text { game, the warehouse does not } \\
\text { have a maximum storage limit, } \\
\text { the warehouse contains a } \\
\text { summary of all company } \\
\text { materials/items stored in all } \\
\text { stores. }\end{array}$ & $\begin{array}{l}\text { Warehouse is made with the } \\
\text { concept of renting, so the fee is } \\
\text { based on rental costs. A } \\
\text { warehouse upgrade means } \\
\text { expanding the building. Can } \\
\text { make sales through warehouse. }\end{array}$ & $\begin{array}{l}\text { Players can choose to buy/rent } \\
\text { warehouse. A warehouse upgrade } \\
\text { means expanding the building. To } \\
\text { increase sales, retail should not } \\
\text { stockout. Cannot make sales } \\
\text { through warehouse }\end{array}$ \\
\hline Forecast module & $\begin{array}{l}\text { Displays the forecast for market } \\
\text { demand in the days ahead as a line } \\
\text { chart. }\end{array}$ & - & - & $\begin{array}{l}\text { Displays the forecast for market } \\
\text { demand in the days ahead as a line } \\
\text { chart. }\end{array}$ \\
\hline $\begin{array}{l}\text { The simula-tion } \\
\text { time calcula-tion in } \\
\text { the game }\end{array}$ & $\begin{array}{l}\text { Depends on facilitator } \\
\text { configuration (in seconds) }\end{array}$ & $\begin{array}{l}\text { Two days ( } 2 \times 24 \text { hours) equals } 1 \\
\text { year }\end{array}$ & One day equals one week & $\begin{array}{l}\text { The player games time calculation } \\
\text { is determined by the administrator } \\
\text { and the facilitator games time } \\
\text { calculation is determined by the } \\
\text { facilitator }\end{array}$ \\
\hline
\end{tabular}

Table 2. Feature mapping of each module.

\begin{tabular}{|c|c|c|}
\hline Module & User & Features \\
\hline \multirow[t]{2}{*}{ Finance } & Facilitator & $\begin{array}{l}\text { - Determine initial cash on hand and overdraft limits at the beginning of the game } \\
\text { - Determine the number of loan options available in the game } \\
\text { - Determine the Loans attribute (loan name, loan term, loan interest, and loan type) } \\
\text { - Determine the loan amount options that players can take }\end{array}$ \\
\hline & Player & $\begin{array}{l}\text { - View the profit \& loss report, balance sheet, and trial balance } \\
\text { - Adding loans }\end{array}$ \\
\hline \multirow[t]{2}{*}{ Retail } & Facilitator & $\begin{array}{l}\text { - Determine the number of city options available where the player can set up his retail } \\
\text { - Determine the attributes of the retail location (city, country, latitude, longitude and population) } \\
\text { - Determine the retail level available in the game and determine the attributes of each retail level (capacity, number of employees, } \\
\text { salaries, rental costs, purchase costs, and overflow costs) }\end{array}$ \\
\hline & Player & $\begin{array}{l}\text { - Rent / buy new retail by selecting a location } \\
\text { - See the sales of each product in each retail per day } \\
\text { - Changing the selling price of the product at each retail } \\
\text { - Upgrade retail (expand retail building) } \\
\text { - Delivering products to other retail/warehouses. }\end{array}$ \\
\hline \multirow[t]{2}{*}{ Ware-house } & Facilitator & $\begin{array}{l}\text { - Determine the number of city options available where the player can set up his warehouse } \\
\text { - Determine the warehouse location attribute (city, country, latitude, longitude, and population) } \\
\text { - Determine the warehouse level available in the game and determine the attributes of each warehouse level (capacity, number of } \\
\text { employees, salaries, rental costs, purchase costs, and overflow costs) } \\
\text { - Determine the fixed cost and variable cost }(/ \mathrm{km}) \text { of delivery }\end{array}$ \\
\hline & Player & $\begin{array}{l}\text { - Rent / buy new warehouse by selecting a location } \\
\text { - Delivering products from warehouse to store } \\
\text { - Enable automatic shipping by specifying the minimum stock quantity in the shop and the quantity of goods to be shipped } \\
\text { - Upgrade warehouse (expand warehouse building) }\end{array}$ \\
\hline \multirow[t]{2}{*}{ Procurement } & Facilitator & $\begin{array}{l}\text { - Determine the number of vendor options available in the game } \\
\text { - Determine the Vendors attributes (name, product offered and its price, lead time, fixed cost, special offer) } \\
\text { - Determine the Special Offers attributes (title, minimum purchase, discount, and cashback) }\end{array}$ \\
\hline & Player & - Purchase products to fill retail/warehouse stock by selecting vendors and selecting the desired number of products \\
\hline Sales & Facilitator & $\begin{array}{l}\text { - Determine the percentage of a player's daily retail sales based on the population of that retail location } \\
\text { - Determine the conditions that must be met if player wants to increase sales } \\
\text { - Determines the percentage increase in sales that occurs if the player meets the requirements } \\
\text { - Determine a random range for sales of each product in each retail } \\
\text { - Determine the minimum and maximum percentage increase in sales during holidays in the game }\end{array}$ \\
\hline Forecast & $\begin{array}{l}\text { Facilitator } \\
\text { Player }\end{array}$ & $\begin{array}{l}\text { - View estimated future sales per product per store in graph form } \\
\text { - View estimated future sales per product per store in graph form }\end{array}$ \\
\hline
\end{tabular}




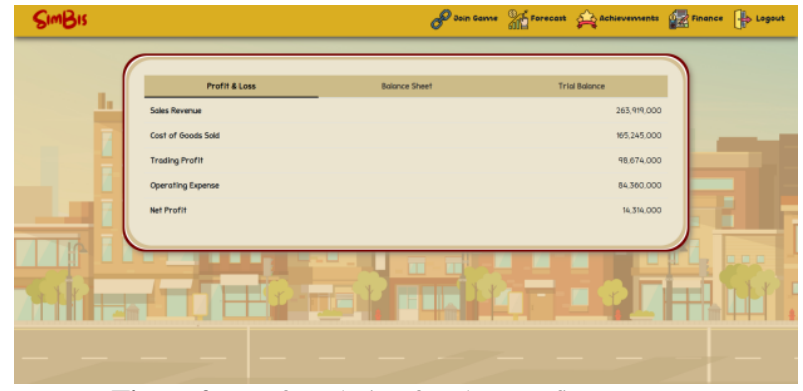

Figure 2. Interface design for players - finance page.

The forecast page (Figure 3) is a page where players can see estimated future retail sales. The estimated sales are displayed in the form of a line chart, making it easier for players to be aware of rising/falling demand.

The loans page (Figure 4) is a page where players can make a loan. By making a loan, players can add cash directly, but some installments must be paid to make up for it. This page displays what loans the player has taken, along with the details of the payments.

The procurement page (Figure 5) is a page where players can buy products from vendors to fill retail or warehouse stock. This page displays the available vendor offers as well as a purchase form that players can fill out. In the purchase form, the player has to select a vendor and select the quantity of the product to buy.

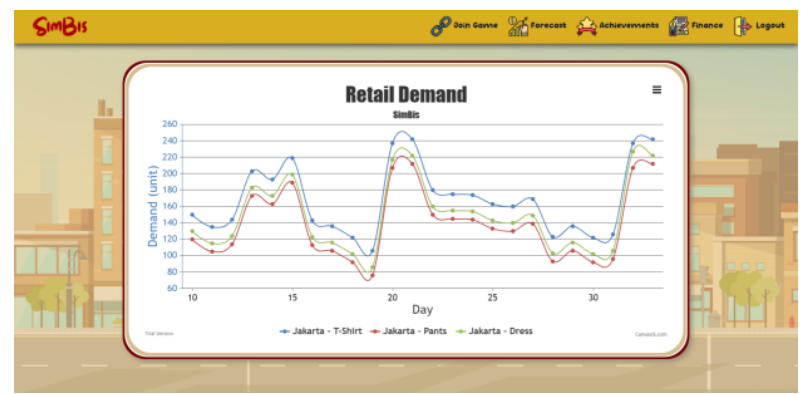

Figure 3. Interface design for players - forecast page.

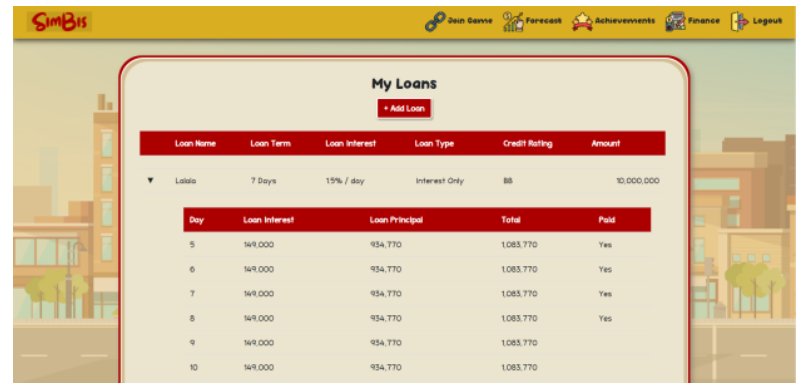

Figure 4. Interface design for players - loans page.

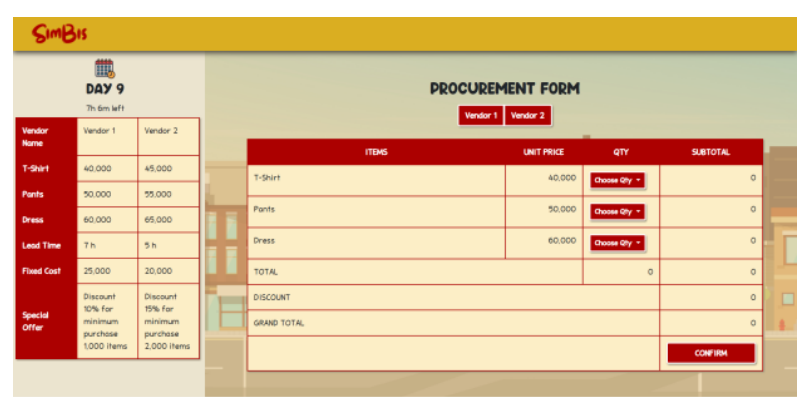

Figure 5. Interface design for players - procurement page.

\subsubsection{For Facilitators}

Interface design for facilitators consists of 4 pages: home page, configuration page, gameplay page, and history page. The home page (Figure 6) is the facilitator's main page that displays a list of facilitator games that have been made by the facilitator and have not ended. A facilitator can run or delete the game.

The configuration page (Figure 7) is a page that displays a list of facilitator games configurations created by the facilitator. These configurations are used in making the game, where the game runs according to the conditions in the configuration.

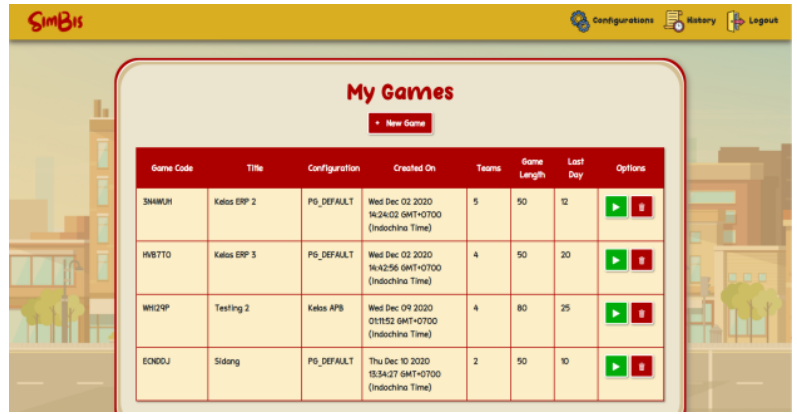

Figure 6. Interface design for facilitators - home page.

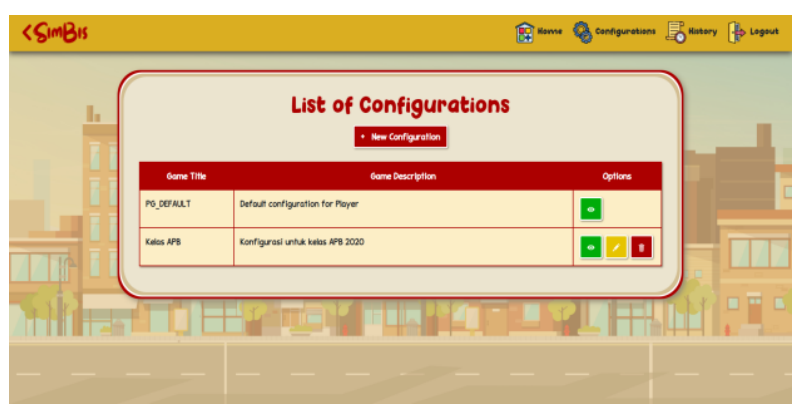

Figure 7. Interface design for facilitators - configuration page.

The gameplay page (Figure 8) is a page where the facilitator can monitor the running game. The facilitator can manage the players' teams on this page, see or edit the game configuration, see the overall current scores, see each team report, and run, pause, reset, and stop the game.

The history page (Figure 9) is a page where the facilitator can see the results of games that have been run before. This page only displays a table containing the title of the game that was run, when the game was run, and the current game code. To see the details of the results, the facilitator can click 'See Details' button.

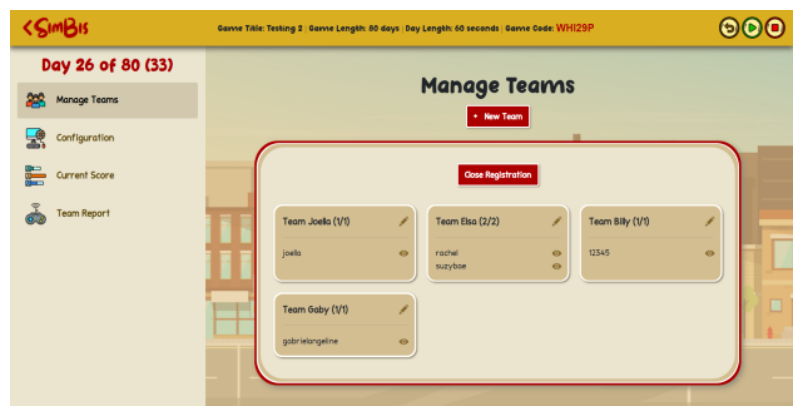

Figure 8. Interface design for facilitators - gameplay page. 


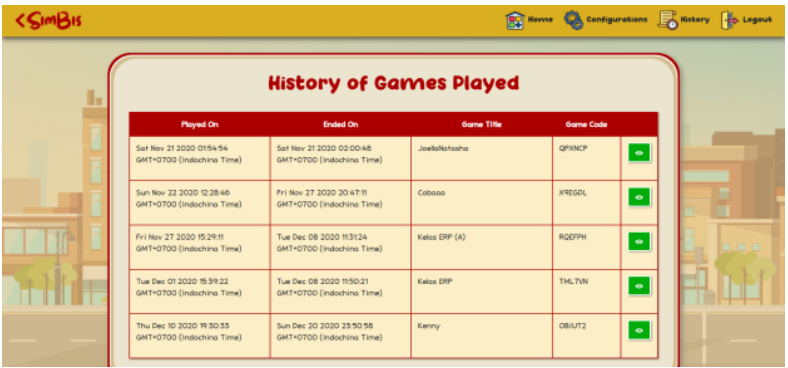

Figure 9. Interface design for facilitators - history page.

\subsubsection{For Administrator}

Interface design for administrator consists of 6 pages: player data page, facilitator data page, player game data page, player games configuration page, game configuration data page, and facilitator game results page. According to the names on the player data page (Figure 10), the administrator can manage the player data. On the facilitator data page, the administrator can manage the facilitator data. On the player game data page (Figure 11), the administrator can see the list of the player. On the player configuration page (Figure 12), the administrator can edit the player configuration. On the game configuration data page, the administrator can manage the game configuration data, and on the facilitator game results page, administrator can see the results of ended facilitator games.

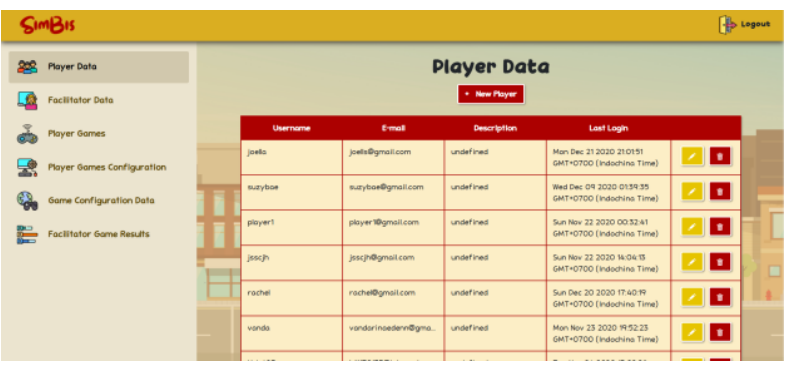

Figure 10. Interface design for administrator - player data page.

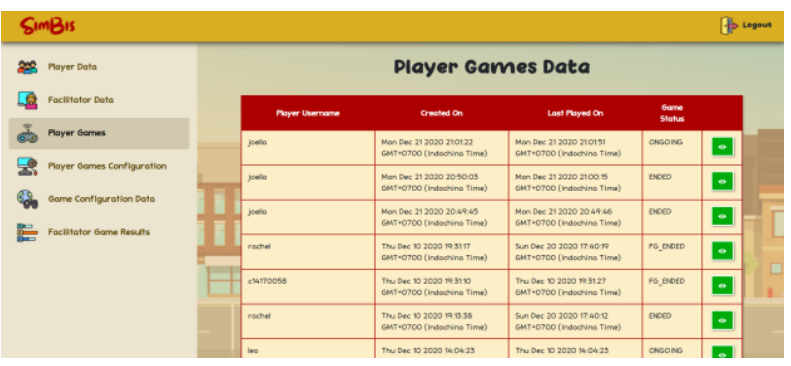

Figure 11. Interface design for administrator-player games data page.

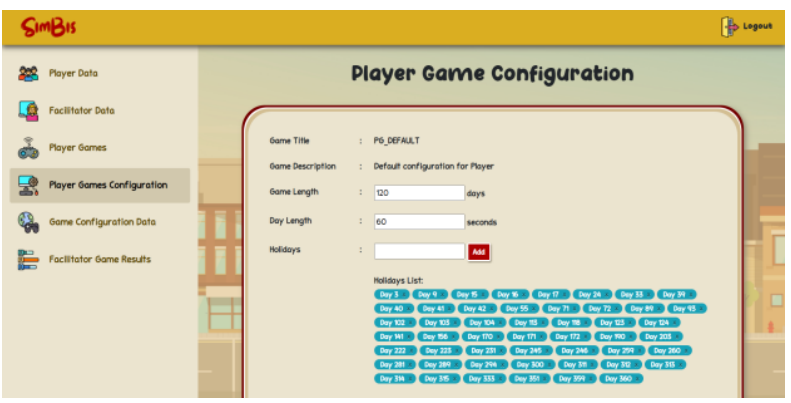

Figure 12. Interface design for administrator-player games configuration page.

\subsection{System Design}

Overall, the games developed in this research can be divided into six main system designs, namely the finance module, retail module, warehouse module, sales module, forecast module, and procurement module.

\subsubsection{Finance module}

Administrators and facilitators can create or edit game configurations. The game configuration is what determines how the game plays. Some of the things in the finance module that can be configured are:

a. Initial Cash on Hand is the initial cash that a player has to build his virtual company.

b. Overdraft Limit is the overdraft limit a player can get. Suppose the overdraft obtained by the player has exceeded the overdraft limit set by the administrator or facilitator. In that case, the player will automatically be declared a failure because the company is bankrupt and confiscated.

c. Available Loans is loan options available in the game. Players can borrow money to increase their cash by choosing a loan provided by an administrator or facilitator.

d. Loan Amount Options are loan amount options that players can obtain. In addition to choosing a loan, players must also choose a loan amount based on the options provided by the administrator and facilitator.

e. Account Payables Limit is the borrowed limit a player can take. The loan fails when a player adds a loan and chooses a nominal amount that exceeds the account payables limit.

In this module, three financial reports can be seen by players, namely profit and loss, balance sheet, and trial balance. In the profit and loss report: Sales Revenue is the total sales revenue during the game, Cost of Goods Sold is the total cost of goods sold during the game, Trading Profit is the total gross profit earned during the game - Trading Profit is obtained from sales revenue minus the cost of goods sold, Operating Expense is the total operating costs that have been paid during the game, Net Profit is the total net profit earned during the game. Net profit is obtained from trading profit minus operating expense.

Next, we will discuss the balance sheet report. The most important thing about this report is that this report must meet the formula: Assets = Liabilities + Equity. Assets are obtained from total cash on hand, plus building, plus inventory value. Liabilities are obtained from total accounts payables and overdrafts. Equity is obtained from the owner's equity and net profit. The last report is a trial balance report. In this report, players can view transaction details for each account. This game has nine accounts, namely cash on hand, building, inventory value, payables account, overdraft, owner's equity, sales revenue, cost of goods sold, and operating expense. The most important thing about this report is that the total debits and the total credits must be the same (balance).

Players can also make loans to increase their cash. In making a loan, players need to choose from available loans by considering the amount of interest, the loan term, and the type of loan. Two types of loans affect how the installment payment is calculated, namely fully amortized and interest only. With interest-only, during the installment period, the player only needs to pay the interest. On the last day, the player has to pay all the loans. Meanwhile, fully amortized divides the installment payments evenly, using the following formula: 
$A=P \times \frac{i}{1-(1+i)^{-t}}$

With:

$A=$ installment amount

$P=$ loan amount

$i=$ loan interest

$t=$ loan term

\subsubsection{Retail and warehouse module}

Some points in the retail and warehouse modules that administrators and facilitators can configure are:

a. Location Map is the map image displayed in the game. With this map image, players can estimate the distance between locations to set up their retails/warehouses.

b. Fixed Shipping Cost is the fixed cost of every shipment made by a player between their retails/warehouses.

c. Shipping Cost is the variable cost of each shipment made by a player between retails/warehouses based on the distance between the retails/warehouses. So, the cost of each shipment is the number of fixed costs (fixed shipping cost) plus the number of variable costs (shipping cost multiplies the distance between retail/warehouse in kilometers).

d. Mileage is the distance traveled kilometers per day from each shipment made by a player between their retailers/ warehouses. This mileage determines the delivery lead time.

e. Available Locations is a location option where players can set up their retail/warehouse.

f. Available Retail Levels are the retail levels available in the game. These available retail levels determine whether a player can increase his retail capacity and how much additional costs are required.

g. Available Warehouse Levels are warehouse levels available in the game. These available warehouse levels determine whether players can increase their warehouse capacity and how much additional costs are required.

In this retail and warehouse module, players can send goods between retails and warehouses. Each time a player makes a shipment, the system calculates the distance to determine the shipping cost and shipping lead time. The system calculates distance based on longitude and latitude, using the following formula:

$D=\sqrt{\left(\text { lat }_{1}-\text { lat }_{2}\right)^{2}+\left(\operatorname{long}_{1}-\operatorname{long}_{2}\right)} \times 111,319$

With:

$D=$ distance $(\mathrm{km})$

lat $_{1}=$ latitude of origin

long $_{1}=$ longitude of origin

lat $_{2}$ = latitude of destination

long $_{2}=$ longitude of destination

\subsubsection{Forecast, sales, and procurement module}

Some points in the forecast, sales, and procurement modules that administrators and facilitators can configure are:

a. Holidays is a list of holidays in the game. Sales will increase during these holidays.

b. Available Products are products that are transacted in the game. c. First Sales is used to determine the quantity of the first sale from retail. First sales is a percentage, where this percentage will be multiplied by the population of the city where the retail is located.

d. Increase Term is a requirement that players must meet in order for their retail sales to increase. The increase term is the number of days, where if the increase term is 5, it means that the player must ensure that their retail does not run out of stock to meet customer demand for 5 consecutive days.

e. Increase of Sales is the increase in sales if the player meets the Increase Term. Increase of sales is in the form of a percentage.

f. Sales Random Range is a random range for the sales of each product. So, the sales of each product every day are always changing.

g. Min Increase During Holidays and Max Increase During Holidays are the minimum and maximum percentage limits used as a random range of sales increases during holidays.

h. Available Vendor's Special Offers are special offers provided by vendors in the game.

i. Available Vendors are the vendors available in the game.

j. Procurement Quantity Options are the purchase quantity options per product that players can order.

Sales are done automatically by the system. The calculation carried out by the system to determine the number of sales for each retail per day is based on random results using the following formula:

$$
\begin{aligned}
A P S= & \frac{C S}{100} \times P O P \\
S P D= & \frac{\left(\frac{S P}{D P} \times 100\right)-100}{100} \times-2 \\
S P P= & \operatorname{rand}\left(\left(A P S \times\left(1-\frac{S R R}{100}\right)\right),\left(A P S \times\left(1+\frac{S R R}{100}\right)\right)\right) \times \\
& (1+S P D) \times(1+H O L)
\end{aligned}
$$

With:

APS (All Product Sales) = overall product sales quantity

CS $($ Current Sales) = current retail sales percentage

$\mathrm{POP}($ Population $) \quad=$ population of the city where retail is located

SPD $($ Sales Price Difference $)=$ the percentage increase $/$ de crease in price based on the selling price

$\mathrm{SP}$ (Sales Price) = the selling price determined by the player

$\mathrm{DP}($ Default Price $) \quad=$ market selling price

SPP $($ Sales Per Product $) \quad=$ sales quantity per product per day

SRR (Sales Random Range) = sales random range determined by admin/facilitator

HOL (Holiday)

$=$ percentage increase in sales by holiday

\subsubsection{Scoring Matrix}

The scoring matrix is the detailed rating of each criterion in the game. The assessment of each player is based on this scoring matrix. The scoring matrix is stored in the form of an array of objects consisting of criteria, scoring, and weight. Scoring is used to determine whether a criterion is considered better if a player's score is higher or lower than other players. 
Weight is the weight rating for each criterion. In the game developed in this study, nine criteria are available: cash on hand, trading profit, operating expense, net profit, operating ratio, overdraft, return on assets, retail stockout, and retail sales. Using these nine criteria as a condition to win the game can indirectly force players to understand and master the concept of business management.

To determine the final score for each team of players, this game uses a ranking system. First of all, the system sorts the position of the players' team on each criterion based on its scoring. Then after determining the position of the player team, the system calculates the value by dividing the position of the player team against the number of player teams and multiplying by the weight of the assessment criteria. For example, team " $\mathrm{A}$ " for the cash on hand criteria is in 2nd place out of 5 player teams and the cash on hand criterion has an assessment weight of $30 \%$, then the team "A" score for the cash on hand criteria is 12 . After getting each score criteria, all the scores are added together and produce the final score for the player team.

\section{System Testing and Evaluation}

\subsection{System Testing}

System testing has been carried out on all features of the three types of users. All features can work well and as expected. Apart from testing the features one by one, in-class testing is also done. Several players accessed the system at the same time. The result was that the game system can work optimally with a maximum limit of about 15 users simultaneously. If more than that, there is a chance that some data will not be updated properly. The test was carried out three times, and the test results are described in Table 3 . The test was carried out using a server with the following specifications:

- Processor : Intel® Xeon® Gold 5118 CPU @ 2.3GHz

- RAM : 4GB

- Storage : 395GB

Table 3. The result of testing the number of user accesses.

\begin{tabular}{ccl}
\hline Testing & Num. of users & \multicolumn{1}{c}{ Data that is not updated properly } \\
\hline 1 & 50 users & Timer and transaction data \\
2 & 25 users & Timer data \\
3 & 15 users & - \\
\hline
\end{tabular}

\subsection{Analysis of the Benefits of Game Implementation}

To answer the research problems, users filled out a questionnaire related to the benefits of the developed game. Users who were respondents to the questionnaire consisted of several lecturers and students because later this game would be used as a learning tool. Each question represents assessable aspects of the game. Users are asked to rate these aspects on a scale of 1-5 (very dissatisfied, dissatisfied, neutral, satisfied, very satisfied).

There were five lecturers and 41 students who filled out this questionnaire. The five lecturers who filled out this questionnaire were lecturers who already understood business processes and were likely to use this game in teaching and learning activities later. 4 out of 5 lecturers have attended training on the use of business process simulation games as a learning tool in the classroom. Then the 41 students who filled out this questionnaire were students from the Enterprise
Resource Planning class who already understood business processes and had used business process simulation games before.

In Table 4, you can see the average and standard deviation of each question. The average of all questions ranges from a value of 4, which means that the user positively responds to the game developed in this study. In addition, the standard deviation of each question is also not too large, which is below 1 , which indicates that the average result can represent all respondents' answers. Table 5 shows the percentage of the response to each question.

Table 4. The questionnaire's result calculation.

\begin{tabular}{|c|c|c|}
\hline Question & Avg & St. Dev. \\
\hline $\begin{array}{l}\text { The interface design of the game "SimBis" is } \\
\text { interesting }\end{array}$ & 4.54 & 0.6568 \\
\hline The game "SimBis" is easy to use & 4.04 & 0.7876 \\
\hline $\begin{array}{l}\text { The business process simulations in the game } \\
\text { "SimBis" is in accordance with the business } \\
\text { process in the real world }\end{array}$ & 3.98 & 0.8025 \\
\hline $\begin{array}{l}\text { The game "SimBis" is suitable as a business } \\
\text { process learning tool. }\end{array}$ & 3.40 & 0.7851 \\
\hline $\begin{array}{l}\text { I believe that using the game "SimBis" can } \\
\text { improve the quality of business process } \\
\text { learning. }\end{array}$ & 4.37 & 0.7105 \\
\hline $\begin{array}{l}\text { Overall, I am satisfied with the game "SimBis" } \\
\text { because it is useful for me }\end{array}$ & 4.20 & 0.7489 \\
\hline $\begin{array}{l}\text { (Especially for Lecturers) I want to use the } \\
\text { game "SimBis" when teaching business } \\
\text { process materials. }\end{array}$ & 4.40 & 0.8944 \\
\hline
\end{tabular}

Table 5. The questionnaire's responses percentage.

\begin{tabular}{ccrrrr}
\hline Question & 1 & \multicolumn{1}{c}{2} & \multicolumn{1}{c}{3} & \multicolumn{1}{c}{4} & \multicolumn{1}{c}{5} \\
\hline 1 & $0 \%$ & $0 \%$ & $8.7 \%$ & $28.3 \%$ & $63 \%$ \\
2 & $0 \%$ & $0 \%$ & $28.3 \%$ & $39.1 \%$ & $32.6 \%$ \\
3 & $0 \%$ & $2.2 \%$ & $26 \%$ & $43.5 \%$ & $28.3 \%$ \\
4 & $0 \%$ & $0 \%$ & $19.6 \%$ & $30.4 \%$ & $50 \%$ \\
5 & $0 \%$ & $0 \%$ & $13 \%$ & $37 \%$ & $50 \%$ \\
6 & $0 \%$ & $0 \%$ & $19.6 \%$ & $41.3 \%$ & $39.1 \%$ \\
7 & $0 \%$ & $0 \%$ & $20 \%$ & $20 \%$ & $60 \%$ \\
\hline
\end{tabular}

\section{Conclusion \& Recommendation}

\subsection{Conclusion}

Based on the results of the questionnaire, the average of all questions ranges from a value of 4 , which means that the user gives a positive response to the games developed in this study. In addition, the standard deviation of each question is not too big, which is below 1, which indicates that the average result can represent all respondents' answers. So it can be concluded that all users are satisfied and get the benefits of the games developed in this study. Users also agree that the games developed in this study are suitable to be a good retail companies business process learning tool.

\subsection{Recommendation}

Based on the developed game along with the results of the analysis, it is suggested that:

- It is necessary to add other business process modules to have a wider scope of business processes and more closely resemble the real business process.

- The game configuration needs to be updated so that the game is not too easy or too difficult to win. 
- The display needs to be improved by adding the information needed by the user so that the display is easier to understand.

The server specifications need to be upgraded. Otherwise, another web server that is more reliable in managing site speed and scalability can be used.

\section{References}

[1]. Bailey, T., Thabtah, F., Wright, M., \& Tran, D. A. (2019). FoodKnight: A mobile educational game and analyses of obesity awareness in children. Health Informatics Journal, 1460458219888405.

[2]. Blazic, A. J., Ribeiro, C., \& Arh, T. (2012). Analysing the required properties of business simulation games to be used in e-learning and education.

[3]. Chuang, M. L. (2020). A web-based simulation game for teaching supply chain management. Management Teaching Review, 5(3), 265-274.

[4]. Gamble, E. M. (April 16, 2020). SimCompanies Simulator Use for an Undergraduate Senior Capstone Course. Retrieved from https://landia-misc.s3-us-west2. amazonaws.com/SimCompanies-Brief-Gamble-EricM-202020200417.01.pdf

[5]. Luna Scott, C. (2015). The Futures of Learning 3: What kind of pedagogies for the 21st century?

[6]. Nasution, M. K. (2018). Penggunaan metode pembelajaran dalam peningkatan hasil belajar siswa. Studia Didaktika, 11(01), 9-16.

[7]. Ngafifi, M. (2014). Kemajuan teknologi dan pola hidup manusia dalam perspektif sosial budaya. Jurnal Pembangunan Pendidikan: Fondasi dan Aplikasi, 2(1).
[8]. Novitri, B. Q., \& Lianto, R. (2019, August). Perancangan Game Edukasi Agama Katolik dengan Metode Finite State Machine. In ENTER (Vol. 2, No. 1, pp. 15- 27).

[9]. Prensky, M. (2003). Digital game-based learning. Computers in Entertainment (CIE), 1(1), 21-21.

[10]. Qian, M., \& Clark, K. R. (2016). Game-based Learning and 21st century skills: A review of recent research. Computers in Human Behavior, 63, 50-58.

[11]. Rosing, M. V., Kemp, N. A., Hove, M., \& Ross, J. W. (2014). Process Tagging-A Process Classification and Categorization Concept. The Complete Business Process Handbook, 1, 123-171.

[12]. Sari, S., Anjani, R., Farida, I., \& Ramdhani, M. A. (2017, September). Using android based educational game for learning colloid material. In Journal of Physics: Conference Series (Vol. 895, No. 1, p. 012012).

[13]. Sparx, G. (2009). The business process model.

[14]. Teguh Martono, K. (2015). Pengembangan Game dengan Menggunakan Game Engine Game Maker. Jurnal Sistem Komputer, 5(1), 23-30.

[15]. Virtonomics. (2018, December). Virtonomics User Guide. Retrieved from https://virtonomics.com/wpcontent/uploads/sites/2/2018/12/UserGuideVirtonomics_en .pdf

[16]. Wankel, C., \& Blessinger, P. (Eds.). (2012). Increasing student engagement and retention using immersive interfaces: Virtual worlds, gaming, and simulation. Emerald Group Publishing.

[17]. Weske, M. (2012). Business process management architectures. In Business Process Management (pp. 333371). Springer, Berlin, Heidelberg.

[18]. Yaoyuenyong, P. (2018). MonsoonSIM 5.2x. 